Article

\title{
The Use of Chalcedonite as a Biosorption Bed in the Treatment of Groundwater
}

\author{
Dorota Papciak (D), Andżelika Domoń *D, Alicja Puszkarewicz and Jadwiga Kaleta
}

Department of Water Purification and Protection, Faculty of Civil, Environmental Engineering and Architecture, Rzeszow University of Technology, Al. Powstancow Warszawy 6, 35-959 Rzeszow, Poland; dpaciak@prz.edu.pl (D.P.); apuszkar@prz.edu.pl (A.P.); jkaleta@prz.edu.pl (J.K.)

* Correspondence: adomon@prz.edu.pl; Tel.: +48-17-865-1949

Received: 3 January 2019; Accepted: 18 February 2019; Published: 21 February 2019

\begin{abstract}
The conducted laboratory tests allowed determination of the efficiency of removing ammonium nitrogen, iron, and manganese in the biofiltration process on chalcedonite beds. The process of water purification was carried out by a single- and two-stage biofiltration method with gravitational and anti-gravitational flow. The study examined the extent to which chemical activation of the bed with potassium manganese (VII) affects the course of the nitrification process and the rate of biofilm formation. The obtained test results indicate that two-stage biofiltration, with initial chemical activation at the first stage of biofiltration, is an effective method for purifying waters with an abnormal content of ammonium nitrogen with simultaneous removal of iron and manganese. Activation of the bed had an effect on, among other things: biofilm formation time, efficiency of removing manganese (II) ions, and oxygen consumption in the biofiltration process. Due to the longer maturation time of the activated bed, the normative value of ammonium nitrogen $\left(<0.39 \mathrm{~N}^{-\mathrm{NH}_{4}}{ }^{+}\right)$ was obtained on the 23rd day of the operation of the filters, and in the non-activated bed on the 14th day. The method of bed preparation did not affect the efficiency of removal of iron compounds.
\end{abstract}

Keywords: biofiltration; chalcedonite deposits; nitrification; removal of iron and manganese

\section{Introduction}

Groundwaters are the main source of drinking water around the world [1,2]. In many cases, groundwater is characterized by an increased content of iron, manganese, and ammonium nitrogen compounds and their presence may contribute to deterioration of the organoleptic quality of the water and discoloration of sanitary facilities, as well as the formation of deposits in the water pipes [1,3-6]. Although iron and manganese are necessary for the proper functioning of the human body, their consumption in excessive amounts, in particular manganese, may be the cause of chronic food poisoning, pulmonary embolism, bronchitis, impotence, nerve damage, or Parkinson's disease [7,8]. In addition, the presence of ammonia increases the consumption of chlorine and hence the numbers of chloramines formed [9].

Groundwater quality mainly depends on natural factors, including aquifer lithology, the quality of water recharge, and groundwater rock interactions, as well as anthropogenic factors, e.g., agriculture, industry, the exploitation of water resources, and urban development [10]. In water intended for consumption, maximum concentrations of iron, manganese, and ammonium nitrogen should not exceed $0.2,0.05$, and $0.5 \mathrm{~g} / \mathrm{m}^{3}$, respectively [11]. However, over $50 \%$ of users of groundwater intakes are exposed to an excessive content of iron and manganese compounds. It is rare that underground water is suitable for direct use for water supply purposes, yet many treatment stations face the need to intensify the water treatment process and modernize their equipment [12-14]. 
Groundwater treatment and purification technologies based on biological methods are popular in European countries and most often include combined removal of iron and manganese, and sometimes also nitrification of ammonium nitrogen by natural or synthetic filtration deposits $[10,15,16]$. In classic iron removal, the abiotic process dominates the biological one [17]. It consists of water aeration, homogeneous oxidation of divalent iron with oxygen dissolved in water, and mechanical separation of precipitated iron (III) hydroxide, which can be assisted by heterogeneous oxidation by catalytic interaction of a ferric coating deposited on grains of filtration material [16]. The biological oxidation plays a role in iron removal mainly in conditions that are unfavorable to the physical and chemical process when they have low $\mathrm{pH}$ and redox potential and very low oxygen content in water [18]. Manganese removal is a result of a chemical process of heterogeneous catalysis, which involves fluid-formed deposits of manganese dioxide, and biological oxidation [15]. The operation of biologically active filters consists of using the metabolic activity of microorganisms for strictly defined transformations, giving the assumed technological effect. An integral element of underground water purification treatment technology, based on biological processes, is the carrier, which plays an important role in them. Depending on the structure and properties of the carrier, it may additionally be adsorbed or ion exchanged, but it may also supply nutrients and buffer the biochemical reaction environment, and the remaining parameters related to the type of carrier that translate into colonization with microorganisms are granulation, surface area, porosity, and ability to produce stable connections between the surface of the carrier and microflora [19-21].

In biosorption beds the carrier-the biofilter filler-plays a special role. Depending on its characteristics, it may serve as an adsorbent, molecular sieve, ion exchanger, and substance for nutrition and buffering of the biochemical reaction environment. The role of microorganisms that cover the bed is also double:

1. Performance of biodecomposition of chemical compounds [20];

2. Cause for biodecomposition of the support material [22].

The sorption qualities of the materials was filled by the biofilter and the capability to stop the microorganisms carried by water cause the biomass embedded on the carrier, along with the gradual depletion of sorption capacity of the biofilter to take over its function, sorbing the substances present in water, processing them for building material, and products of biochemical changes providing the energy for cells.

Groundwater purification technology is not as complicated as surface water treatment technology. However, this process is more difficult when, in addition to iron (which can usually be easily removed in a traditional aeration and filtration system), there are also other admixtures, such as manganese (II), ammonium nitrogen, or organic compounds [14,22-25]. The physicochemical methods used to remove iron, manganese, and ammonium nitrogen from water include adsorption, ion exchange, membrane processes, filtration, and chemical oxidation $[9,26]$.

The pollution of groundwater with nitrogen compounds, especially ammonium nitrogen, which has been observed in recent years, requires a constant search for unconventional and highly effective purification processes. The methods used so far either do not always give satisfactory results or they require a significant financial investment. The biofiltration process executed in devices involving biofilm formation on a solid substrate is the most popular method for purifying groundwater from excessive amounts of ammonium nitrogen [27]. Filtration through biosorbent beds is considered to be a highly effective process but at the same time, its effectiveness depends on many factors. In addition to appropriate selection of the carrier, they include the appropriate selection of process parameters and treatment technology adapted to the properties and composition of the treated water. The methodology of testing the technological suitability of filtration materials for the execution of a specific groundwater treatment task requires a series of studies to measure its potential effectiveness [28,29].

Using a continuous sorption system allows a better approach to real industrial applications. A few models that can describe these processes have been reported in the literature [22,30]. However, 
only a limited number of references exist on the modelling of the combined and simultaneous removal of the above pollutants [6,9]. Stembal et al. attempted to estimate the optimal dimensions of a biofilter for the simultaneous removal of iron, manganese, and ammonia in a groundwater treatment plant [15]. Consequently, in packed bed bioreactors, such as trickling filters, bio-sand filters, etc., a more general equation is frequently used. Katsoyiannis and Zouboulis also attempted to model the process of simultaneous iron and manganese removal. They state that removal kinetics of contaminants during water treatment is an important issue, as it could provide information about the time required for efficient removal of a specific contaminant, which is necessary when designing treatment units. Furthermore, reaction rates can be estimated from the results of kinetic analysis and compared to those for abiotic removal. They found that biologically mediated manganese and iron removal followed a first-order reaction rate, presenting half-lives of 3.98 and $0.9 \mathrm{~min}$, respectively. Their kinetic results also indicated that rates of manganese and iron oxidation were several orders of magnitude higher than those for abiotic oxidation [31].

Among the materials that can be used as biosorbent beds, chalcedonites deserve particular attention. Their chemical composition and physical properties create opportunities for multi-purpose use. Characteristics of chalcedonites are influenced by the forms of $\mathrm{SiO}_{2}$ minerals that build them, as well as certain amounts of calcium, magnesium, aluminum, iron, and manganese oxides. Chalcedonites are also characterized by a large specific surface area and a large volume of macropores (slightly higher than in the case of anthracite coal), which is important for biological processes [32,33]. Chalcedonite due to the greater specific surface area and the volume of macropores creates better conditions for immobilization of microorganisms and the development of the biofilm. The research carried out so far shows that the effectiveness of the nitrification process is influenced by the presence of both iron and manganese [20].

Some of the removal of manganese beds requires activation with potassium manganate (VII) solution. In the case of a significant disproportion between the concentration of manganese (II) ions and ammonium nitrogen, the water treatment process is based on the differentiation of mechanisms and the use of biological nitrification as the main process for removing ammonium nitrogen. Therefore, it has become necessary to investigate whether the activation of the bed will affect the growth of nitrifying bacteria and the efficiency of ammonium nitrogen removal.

The main goal was to determine whether the presence of iron and manganese affects the course of the process of biological oxidation of ammonium nitrogen, or changes in the oxygen content during the purification process affect the inhibition of the nitrification process.

\section{Materials and Methods}

The tests were carried out on a laboratory scale on model filters filled with a chalcedonite deposit (Table 1). The water purification process was carried out by single- and two-stage biofiltration, with anti-gravitational flow at $\mathrm{I}^{\circ}$ filtration and gravitational flow at $\mathrm{II}^{\circ}$ filtration. The model filtration system worked with a flow rate of approximately $Q=5 \mathrm{dm}^{3} / \mathrm{h}$, and the working time was $\mathrm{T}=6 \mathrm{~h} / \mathrm{d}$. The study analyzed the efficiency of ammonium nitrogen, iron, and manganese removal in three systems, as follows:

- Water I: single-stage biofiltration on a bed pre-activated with potassium manganese (VII) solution,

- Water II: two-stage biofiltration; $I^{\circ}$ filtration on a bed pre-activated with potassium manganese (VII), II ${ }^{\circ}$ filtration on a natural bed,

- Water III: two-stage biofiltration on beds without pre-activation (Figure 1). 


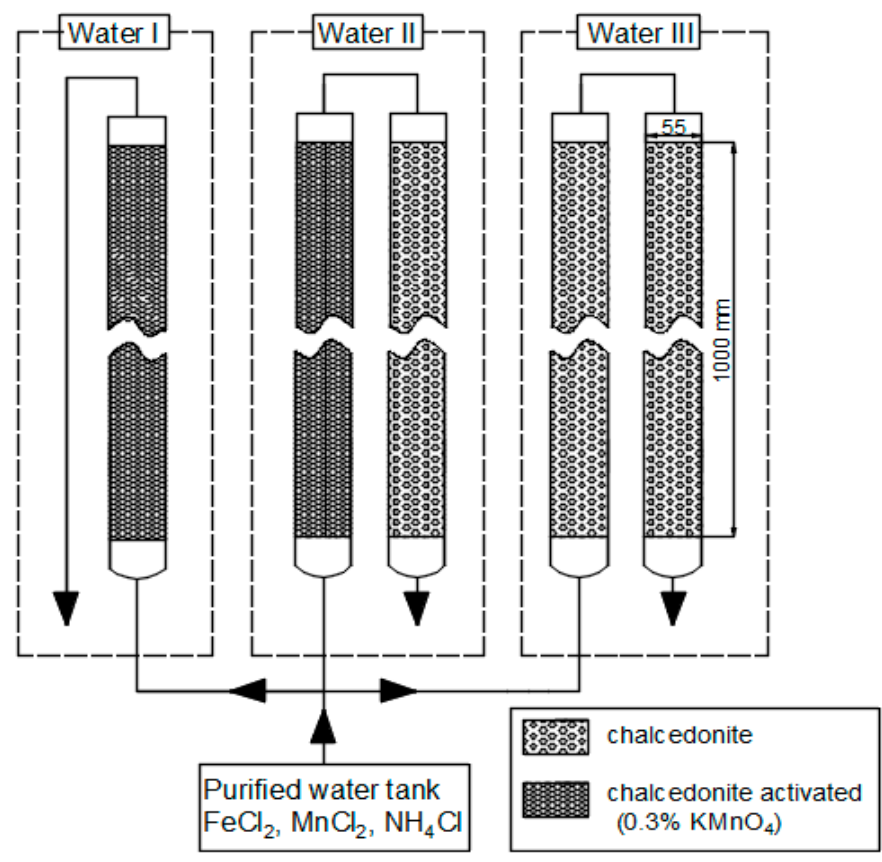

Figure 1. Scheme of the test stand.

Table 1. Parameters of the model filters.

\begin{tabular}{cccc}
\hline Parameter & Value & \\
\hline Height & & $1.0 \mathrm{~m}$ & \\
Diameter & & $0.055 \mathrm{~m}$ & \\
Filtration speed & $2-3 \mathrm{~m} / \mathrm{h}$ & \\
of water flow through & $\mathrm{I}^{\circ}$ filtration & & anti-gravitational \\
the bed & $\mathrm{Ii}^{\circ}$ filtration & & gravitational \\
\hline
\end{tabular}

The activation process consisted of a single flooding of the bed with potassium manganese (VII) solution and then leaving it for $24 \mathrm{~h}$. The calculated dose of $\mathrm{KMnO}_{4}$ necessary to activate the bed was $\mathrm{D}=2.5 \mathrm{~g} / \mathrm{dm}^{3}$ deposit $(\mathrm{D}=1.72 \mathrm{~g} / \mathrm{kg}$ deposit $)$.

The process of transition from the activation of the bed to the work cycle was carried out by rinsing the filter until manganese ions were no longer present in the leak. During the tests, the filters were not rinsed. In the first 7 days, a biopreparation containing nitrifying bacteria was introduced into the filters to accelerate the formation of the biofilm

A model solution was used for feeding the filtration systems. The solution was prepared on the basis of mains water containing (Table 2):

- Ammonium nitrogen at a dose of about $2.0-3.0 \mathrm{~g} \mathrm{~N}^{-\mathrm{NH}_{4}}+\mathrm{m}^{3}$,

- Manganese at a dose of about $1.0 \mathrm{~g} \cdot \mathrm{Mn} / \mathrm{m}^{3}$,

- Iron at a dose of about $1.0 \mathrm{~g} \mathrm{Fe} / \mathrm{m}^{3}$.

Table 2. List of reagents used in the research.

\begin{tabular}{cccc}
\hline Product Name & Chemical Formula & Grade & Source of Purchase \\
\hline Ammonium chloride & $\mathrm{NH}_{4} \mathrm{Cl}$ & & Avantor Performance \\
Manganese (II) chloride tetrahydrate & $\mathrm{MnCl}_{2} \cdot 4 \cdot \mathrm{H}_{2} \mathrm{O}$ & Pure p. a. & $\begin{array}{c}\text { Materials Poland S.A. } \\
\text { (formerly POCH.S.A.) }\end{array}$ \\
Iron (II) chloride tetrahydrate & $\mathrm{FeCl}_{2} \cdot 4 \cdot \mathrm{H}_{2} \mathrm{O}$ & & \\
Potassium manganese (VII) & $\mathrm{KMnO}_{4}$ & & \\
\hline
\end{tabular}

The reagents used in the study are included in Table 3. 
Table 3. The physicochemical quality of water directed to biofilters.

\begin{tabular}{ccccccc}
\hline Parameter & Min & Max & Mean & Median & SD & N \\
\hline Ammonium Nitrogen & 0.50 & 3.70 & 2.49 & 2.50 & 0.62 & 57 \\
Nitrite Nitrogen & 0.00 & 2.26 & 0.37 & 0.06 & 0.61 & 57 \\
Nitrate Nitrogen & 0.02 & 3.58 & 2.01 & 2.00 & 0.85 & 57 \\
Manganese & 0.86 & 1.80 & 1.06 & 1.03 & 0.18 & 57 \\
Iron & 0.78 & 1.17 & 1.02 & 1.00 & 0.08 & 57 \\
Dissolved Oxygen & 5.10 & 10.84 & 8.26 & 8.45 & 1.31 & 55 \\
pH & 7.13 & 7.70 & 7.43 & 7.46 & 0.16 & 55 \\
\hline
\end{tabular}

A red-brown-yellow version of chalcedonite with a granulation of $1.0-2.0 \mathrm{~mm}$ was used as the filling for the filters; after thorough rinsing, the chalcedonite was dried and roasted at a temperature of $550{ }^{\circ} \mathrm{C}$. The properties of chalcedonite are shown in Table 4 . Selected physicochemical parameters of the inflow and outflow water from the model filtration columns were determined according to the methods listed in Table 5.

Table 4. Properties of chalcedonite [34,35].

\begin{tabular}{|c|c|c|c|c|c|}
\hline \multicolumn{3}{|c|}{ Physical Properties } & \multicolumn{3}{|c|}{ Chemical Composition } \\
\hline Parameter & Unit & Range & Parameter & Unit & Range \\
\hline Specific density & $\mathrm{t} / \mathrm{m}^{3}$ & $2.62-2.67$ & $\mathrm{SiO}_{2}$ & $\%$ & $94.0-99.0$ \\
\hline Bulk density & $\mathrm{t} / \mathrm{m}^{3}$ & $1.0-2.0$ & $\mathrm{Al}_{2} \mathrm{O}_{3}$ & $\%$ & $0.4-3.6$ \\
\hline Porosity & $\%$ & $15-30$ & $\mathrm{Fe}_{2} \mathrm{O}_{3}$ & $\%$ & $0.1-0.8$ \\
\hline Impregnability & $\%$ & 4-10 & $\mathrm{CaO}$ & $\%$ & $0.1-1.2$ \\
\hline Compressive strength & $\mathrm{MPa}$ & $60-120$ & $\mathrm{MgO}$ & $\%$ & $0.0-0.3$ \\
\hline Abrasion in the Devala drum & $\%$ & 6-15 & $\mathrm{Na}_{2} \mathrm{O}$ & $\%$ & $0.04-0.2$ \\
\hline Oil number & $\mathrm{g} / 100 \mathrm{~g}$ meal & 26 & $\mathrm{~K}_{2} \mathrm{O}$ & $\%$ & $0.1-0.5$ \\
\hline
\end{tabular}

Table 5. Methodology of physicochemical determinations of water parameters.

\begin{tabular}{|c|c|c|}
\hline Parameter & Unit & Analytical Method/Standard \\
\hline Ammonium nitrogen & $\mathrm{g} \mathrm{N}-\mathrm{NH}_{4}{ }^{+} / \mathrm{m}^{3}$ & $\begin{array}{l}\text { Colorimetric method with Nessler's reagent using } \\
\text { UV-Vis Spectrophotometer (DR 5000, Hach-Lange, } \\
\text { Germany, Europe), method number } 8155\end{array}$ \\
\hline Nitrite nitrogen & $\mathrm{g} \mathrm{N}-\mathrm{NO}_{2}-/ \mathrm{m}^{3}$ & $\begin{array}{l}\text { Colorimetric method by Nitrite Test Merck } 1.14408 \\
\text { (Germany, Europe), method number } 8507\end{array}$ \\
\hline Nitrate nitrogen & $\mathrm{g} \mathrm{N}-\mathrm{NO}_{3}-/ \mathrm{m}^{3}$ & $\begin{array}{l}\text { Colorimetric method with sodium salicylate using } \\
\text { UV-Vis Spectrophotometer (DR 5000, Hach-Lange, } \\
\text { Germany, Europe), method number } 8039\end{array}$ \\
\hline Dissolved oxygen & $\mathrm{g} \mathrm{O}_{2} / \mathrm{m}^{3}$ & $\begin{array}{l}\text { Electrochemical method using a HQ30D Dissolved } \\
\text { Oxygen Meter (Hach-Lange, Germany, Europe) }\end{array}$ \\
\hline Manganese & $\mathrm{g} \mathrm{Mn} / \mathrm{m}^{3}$ & $\begin{array}{c}\text { Colorimetric method using UV-Vis Spectrophotometer } \\
\text { (DR 5000, Hach-Lange, Germany, Europe), method } \\
\text { number } 8149\end{array}$ \\
\hline Iron & $\mathrm{g} \mathrm{Fe} / \mathrm{m}^{3}$ & $\begin{array}{l}\text { Spectrophotometric method by the rhododendron method } \\
\text { using UV-Vis Spectrophotometer (DR 5000, Hach-Lange, } \\
\text { Germany, Europe), method number } 8008\end{array}$ \\
\hline
\end{tabular}

\section{Results}

Based on the obtained results, it can be concluded that purification of groundwater on chalcedonite beds is an effective process in terms of ammonium nitrogen removal. In the case of single-stage filtration (water 1) in the first days of the experiment, the reduction of $\mathrm{NH}_{4}{ }^{+}$content was due to the sorption properties of chalcedonite with an average effectiveness of $16.5 \%$, however, already from day 31 , it was due to the biochemical processes (Figure 2). The process efficiency was maintained at a high level of 60 to $100 \%$. During this period, values in the range $0-0.7 \mathrm{~N}^{-\mathrm{NH}_{4}}{ }^{+}$were obtained in the filtrate, with a standard deviation of 0.22 . The ammonium nitrogen was removed to a level below the permissible norm of $0.39 \mathrm{~g} \mathrm{~N}-\mathrm{NH}_{4}{ }^{+} / \mathrm{m}^{3}$ as early as the 23rd day of the experiment (Figure 2). From day 31, an 
increase in the nitrite nitrogen content in purified water was observed, indicating the beginning of the first phase of the nitrification process. The concentrations of nitrite nitrogen were in the range from 0.008 to $2.35{\mathrm{~g} \mathrm{~N}-\mathrm{NO}_{2}}^{-} / \mathrm{m}^{3}$ and from day 24 , exceeded the permissible value of $0.15 \mathrm{~g} \mathrm{~N}^{-\mathrm{NO}_{2}-} / \mathrm{m}^{3}$. It was only after the 59th day of the experiment that the content of nitrites decreased, indicating that the nitrification process had been carried out in full. The beginning of the second phase of the nitrification process, characterized by the increase of nitrates in the treated water, occurred after the 51st day of the experiment (Figure 2).
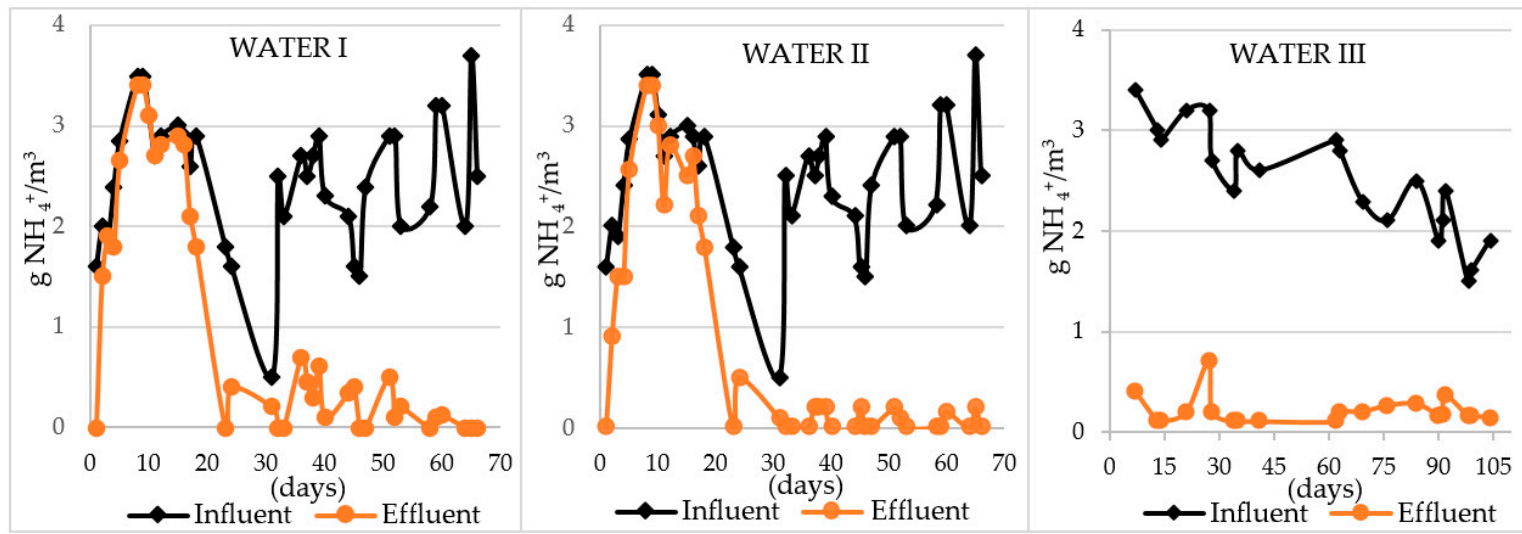

Figure 2. Change in the content of ammonium nitrogen compounds after biofiltration on the chalcedonite bed in the analyzed systems.

Introduction of the second degree of biofiltration (water II) additionally increased the efficiency of ammonium nitrogen removal, and from day 33 the $\mathrm{NH}_{4}{ }^{+}$values were on a level from 0 to $0.2 \mathrm{~g} \mathrm{~N}$ $\mathrm{NH}_{4}{ }^{+} / \mathrm{m}^{3}$, with a standard deviation of 0.22 (efficiency $69-100 \%$ ) (Figure 3). The longer contact time of the treated water with the filtration material contributed to the increased microbiological activity of the beds. The increase in the content of nitrites in the treated water was observed from the first days of the bed's operation (phase I of the nitrification process), and the increase of nitrates in the spill occurred from day 24 (phase II of the nitrification process) (Figure 3).
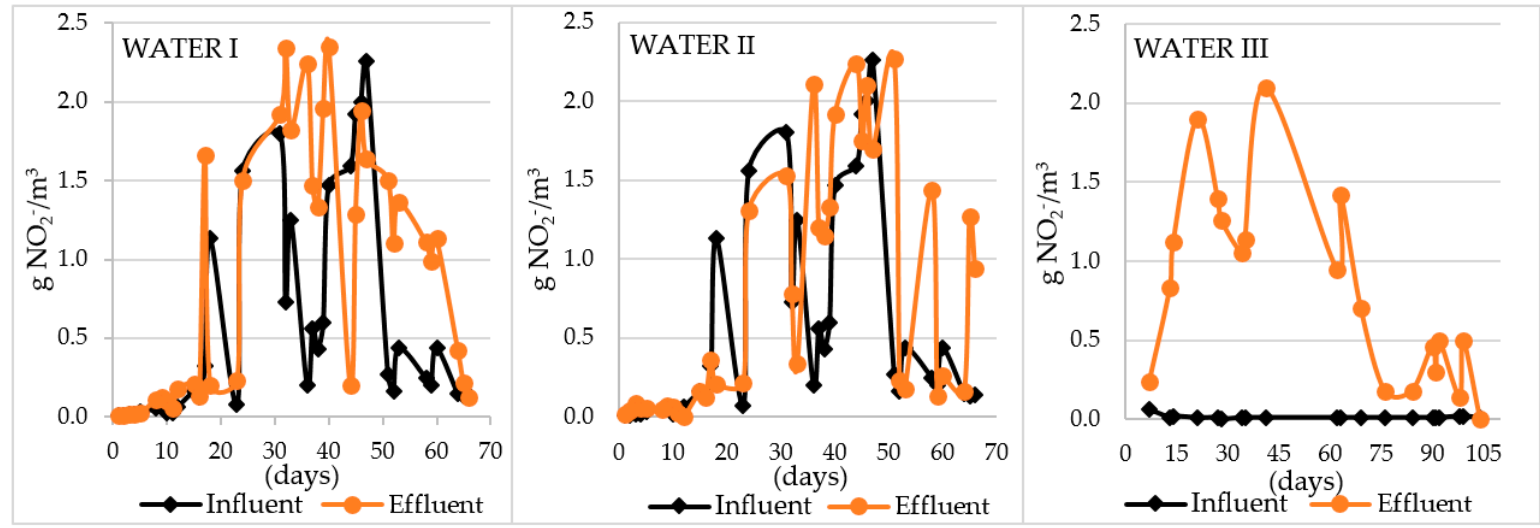

Figure 3. Change in the content of nitrite nitrogen compounds after biofiltration on the chalcedonite bed in the analyzed systems.

In the water treatment system without pre-activation of the bed (water III), the time of biofilm formation (maturation of the bed) was comparable to the two-stage biofiltration system with pre-activation (water II). In this case, a higher efficiency of ammonium nitrogen removal was observed from the first days of the biofilter's operation (effectiveness for the entire test period was 78-97\%) and the permissible value of $0.39 \mathrm{mg} \mathrm{N}-\mathrm{NH}_{4}{ }^{+} / \mathrm{m}^{3}$ was obtained more quickly (on the 7 th day) (Figure 4). The values in the outflow were from 0 to $0.7 \mathrm{~N}^{-\mathrm{NH}_{4}}{ }^{+}$, with a standard deviation of 0.14 . Among the 
samples analyzed, as many as $90 \%$ met the requirements for water intended for consumption. For comparison, in the system with a chemically activated bed, the required level of ammonium nitrogen was achieved only on the 24th day of the filter's operation.
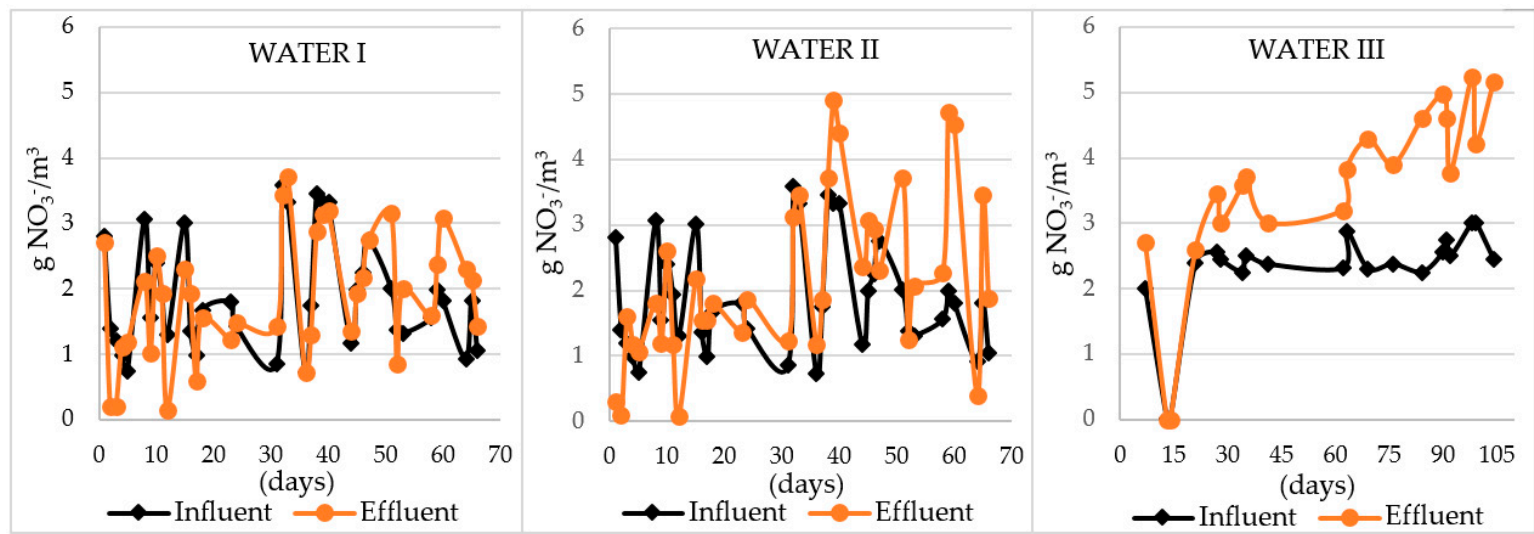

Figure 4. Change in the content of nitrate nitrogen compounds after biofiltration on the chalcedonite bed in the analyzed systems.

The obtained test results confirm the effectiveness of the biofiltration process on the chalcedonite beds in the removal of ammonium nitrogen from groundwater. Regardless of the analyzed variant, from day 32 , the efficiency oscillated in the range from $75 \%$ to $100 \%$. In the initial phase of the experiment, a less effective $\mathrm{NH}_{4}{ }^{+}$elimination was observed in the activated bed system (water III). This phenomenon was caused by a longer time of the formation of the nitrifying biofilm, as evidenced by smaller changes in the content of nitrite and nitrate ions as compared with changes occurring on the non-activated bed (Figures 2-4).

The effectiveness of manganese removal was highest in a two-stage biofiltration system activated with $\mathrm{KMnO}_{4}$ solution (water II) (Figure 5). In this case, the efficiency was at a level of $52 \%-99 \%$ and in $30 \%$ of the analyzed samples, values below $0.05 \mathrm{~g} \mathrm{Mn} / \mathrm{m}^{3}$ were achieved. Chalcedonite grains activated with the $\mathrm{KMnO}_{4}$ solution are covered with $\mathrm{MnO}_{2}$ coating and sorb and catalyze the oxidation of manganese at a much faster rate than the unactivated bed. However, the use of only single-stage filtration (water I) did not allow us to obtain satisfactory results in terms of Mn removal either (Figure 5).
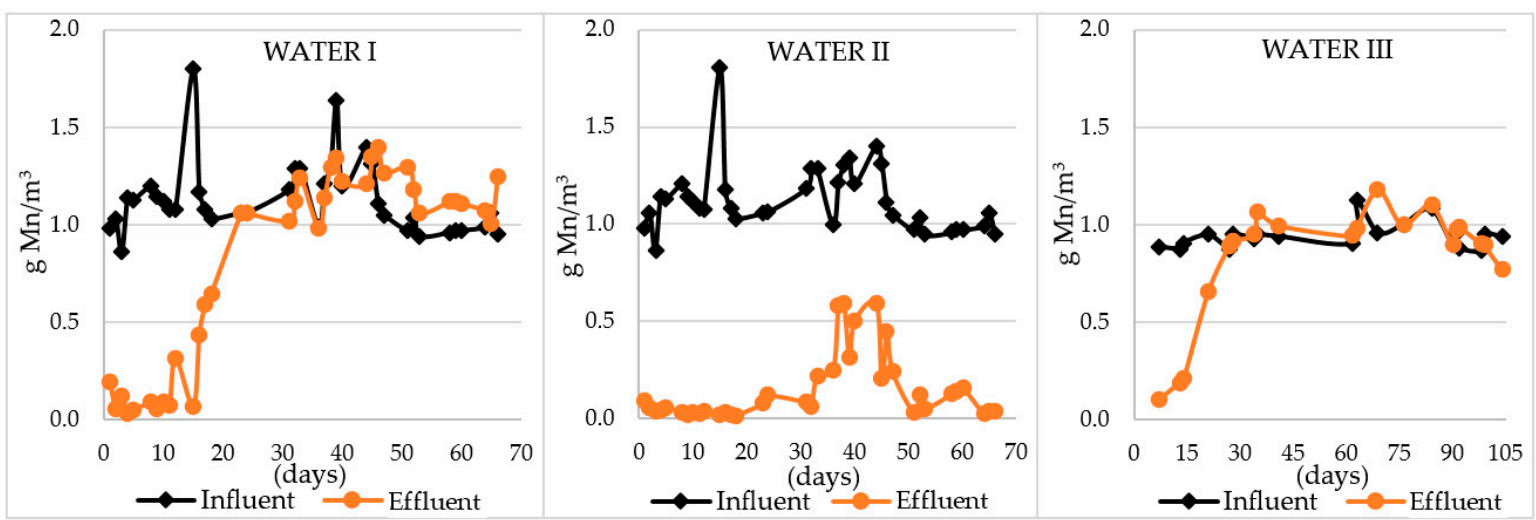

Figure 5. Change in the content of manganese compounds after biofiltration on the chalcedonite bed in the analyzed systems.

On the chemically unactivated bed (water III), a reduction in the concentration of manganese after the biofiltration process was observed only in the initial days (up to day 21). This was caused by the low sorption properties of chalcedonite. Over time, not only was the efficiency of manganese 
removal reduced but more manganese was introduced into the treated water (Figure 5). The reason for this phenomenon could have been the reaction of the produced manganese dioxide with the nitrites generated in the nitrification process. A similar relationship was observed in the single-stage biofiltration system (water I).

After the biofiltration process on the chalcedonite beds, iron concentrations in the analyzed water did not exceed the permissible value of $0.2 \mathrm{~g} \mathrm{Fe} / \mathrm{m}^{3}$ [12] (Figure 6). The exception was one sample taken from system I and II on the first working day of the filter, for which a value of 1.2 and $1.087 \mathrm{~g}$ $\mathrm{Fe} / \mathrm{m}^{3}$ was recorded. The values of iron on the outflow from biofilters ranged from 0 to 0.15 (average standard deviation was 0.03 ). The obtained results indicate that the chemical activation of the bed and the number of filtration stages did not affect the efficiency of the iron removal process (Figure 6).
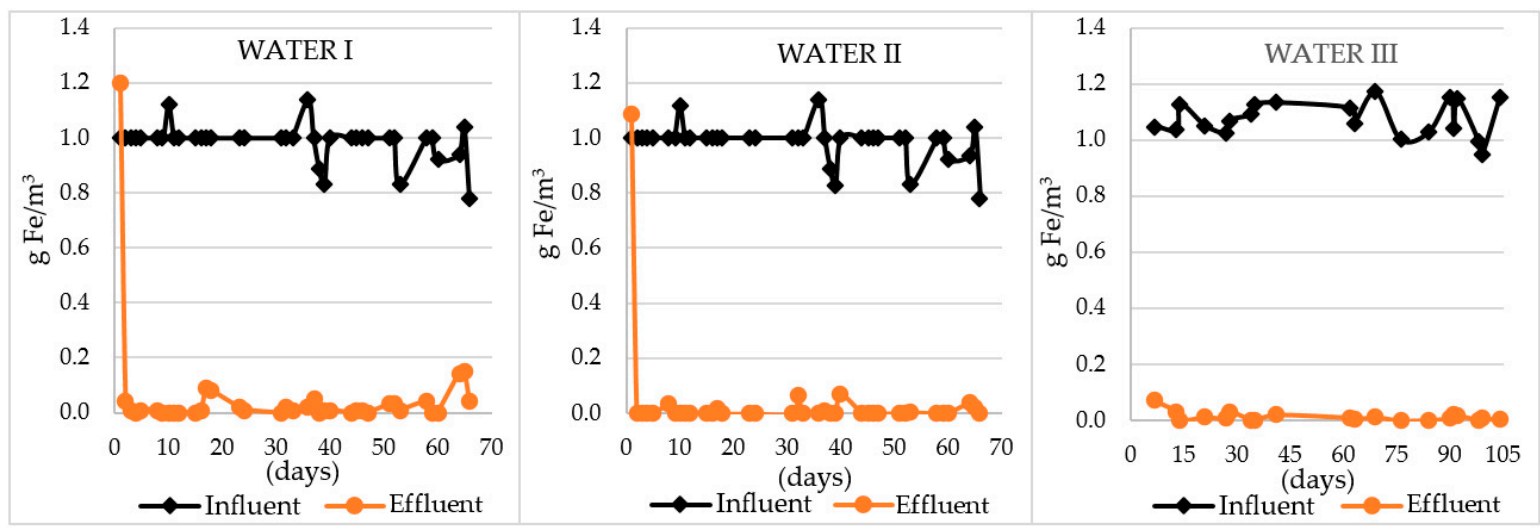

Figure 6. Change in the content of iron compounds after biofiltration on the chalcedonite bed in the analyzed systems.

Research on the biofiltration process on sand beds carried out by Yang et al. [3] also showed a high efficiency of iron removal (below $0.2 \mathrm{~g} / \mathrm{m}^{3}$ ) from the first days of the experiment. Iron in the form of $\mathrm{Fe}^{2+}$ at $\mathrm{pH}>5$ could also be chemically oxidized with the oxygen present in the water [1]. Values < $0.5 \mathrm{NH}_{4}{ }^{+}$were obtained on the 10th day of the filter's operation and the removal of Mn maintained at a constant low level was observed after the 56th day of the filter's operation.

On the basis of the results depicted in Figures 5 and 6, the capacity of the bed in relation to iron was estimated at approximately $0.7 \mathrm{~g} / \mathrm{dm}^{3}$ chalcedonite and filtration was not carried out to the point of exhaustion. In the case of manganese, the capacity of the bed was only $0.19 \mathrm{~g} / \mathrm{dm}^{3}$ chalcedonite.

In comparison with other chemically-active sorption deposits on the basis of silicate media, chalcedonite has a lower level of sorption capacity (Table 6). However, it is necessary to indicate that the values of this parameter were determined by the producers of deposits for model solutions in the optimum conditions of filtration.

Table 6. The of chemically active filtration materials based on silica carriers.

\begin{tabular}{cccc}
\hline \multirow{2}{*}{ Filtration Materials } & \multicolumn{2}{c}{ The Sorption Capacity } & \multirow{2}{*}{ References } \\
\cline { 2 - 3 } & $\mathbf{g ~ F e} / \mathbf{d m}^{\mathbf{3}}$ deposits & $\mathbf{g ~ M n ~} / \mathbf{d m}^{\mathbf{3}}$ deposits & \\
\hline MTM $^{\circledR}$ & 1,3 & 0,6 & {$[36,37]$} \\
GreensandPlus $^{\mathrm{TM}}$ & 1,3 & 0,6 & {$[38,39]$} \\
\hline
\end{tabular}

In the case of catalytic deposits on the basis of manganese ores, i.e., G1, Defeman, Multiman $3 \mathrm{M}$, Pyrolox Filox-R, MetalEase, the sorption capacity is not determined because their properties are not exhausted. Yet, the producers of filtration deposits determine the maximum contents of iron and manganese in the water supplied to the filter, thus indicating the scope of the effective use of a catalytic ore [40-45]. 
Dissolved oxygen is a very important factor affecting the growth rate of microorganisms, as well as the efficiency, type, and rate of metabolite production. Changes to the oxygen content in the biofiltration process in the analyzed systems are shown in Figure 7 . The oxygen consumption in water I and II was in the range $0.1-5.2 \mathrm{~g} \mathrm{O}_{2} / \mathrm{m}^{3}$ and from the 51st day of the experiment, a greater reduction in the content of $\mathrm{O}_{2}$ in the treated water was noted. The increase in oxygen consumption in connection with the increase of nitrate nitrogen and the reduction of nitrite nitrogen may indicate higher activity of microorganisms on the bed and the occurrence of biological processes, i.e., nitrification, taking place. Oxygen could also have been used to oxidize iron compounds. In water III, the consumption was in the range from 1.42 to $5.23 \mathrm{~g} \mathrm{O}_{2} / \mathrm{m}^{3}$ (Figure 7).
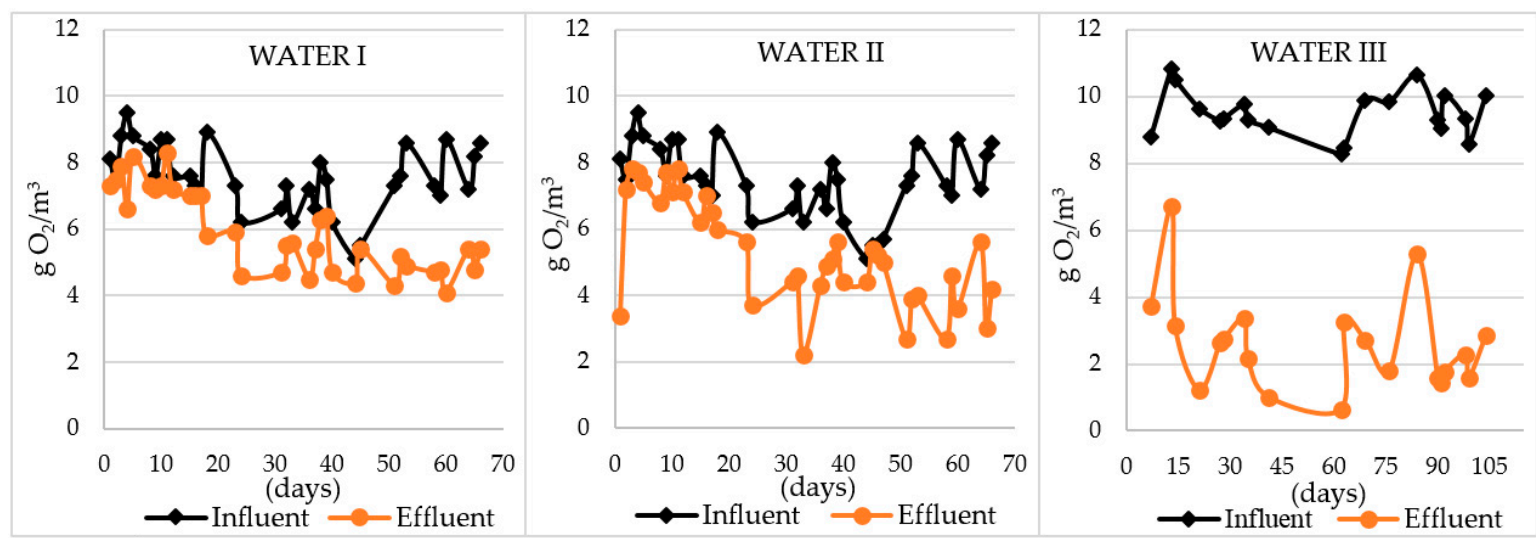

Figure 7. Change in the content of dissolved oxygen after biofiltration on the chalcedonite bed in the analyzed systems.

\section{Discussion of Results}

The research study mainly focused on the removal of ammonium nitrogen in the nitrification process in the presence of iron and manganese. Therefore, iron and manganese sorption isotherms were not determined and the sorption capacity of the chalcedonite deposits was not calculated. The research enabled the observation of the effect of activation of the deposit with potassium manganese (VII) on the effectiveness of biotransformation of ammonium nitrogen and the activity of nitrifying bacteria. The activity of microorganisms was assessed by ammonium nitrogen removal efficiency. Chemical activation was necessary because non-activated chalcedonite removes iron but does not remove manganese. The creation of a catalytic $\mathrm{MnO}_{2}$ coating enabled the simultaneous removal of iron, manganese, and ammonium nitrogen. The creation of a catalytic $\mathrm{MnO}_{2}$ coating and can be carried out with 2 methods: self-activation of chalcedonite by filtration of water containing manganese (this is a $2-3$ month long process), or by chemical activation continuously or periodically with potassium manganese (VII).

The creation of a catalytic $\mathrm{MnO}_{2}$ coating enabled the simultaneous removal of iron, manganese, and ammonium nitrogen. The manganese (II) dissolved in water is adsorbed on the surface of manganese dioxide, where in sequence according to theoretical reactions (1) or (2) it undergoes the oxidation of Mn (II) to Mn (III).

$$
\begin{gathered}
\mathrm{Mn}(\mathrm{OH})_{2}+\mathrm{MnO}(\mathrm{OH})_{2} \rightarrow \mathrm{Mn}_{2} \mathrm{O}_{3}+2 \mathrm{H}_{2} \mathrm{O} \\
\mathrm{Mn}(\mathrm{OH})_{2}+2 \mathrm{MnO}(\mathrm{OH})_{2} \rightarrow \mathrm{Mn}_{3} \mathrm{O}_{4}(\mathrm{OH})_{2}+2 \mathrm{H}_{2} \mathrm{O}
\end{gathered}
$$

At the same time, some of the manganese dioxide on the surface of the medium is reduced from the fourth to the third degree of oxidation. Subsequent reactions take place (3) or (4), in which the trivalent manganese in reaction products (1) and (2) is oxidized to tetravalent with oxygen dissolved in water:

$$
\mathrm{Mn}_{2} \mathrm{O}_{3}+1 / 2 \mathrm{O}_{2}+\mathrm{H}_{2} \mathrm{O} \rightarrow 2 \mathrm{MnO}(\mathrm{OH})_{2}
$$




$$
\mathrm{Mn}_{3} \mathrm{O}_{4}(\mathrm{OH})_{2}+1 / 2 \mathrm{O}_{2}+\mathrm{H}_{2} \mathrm{O} \quad \rightarrow \quad 3 \mathrm{MnO}(\mathrm{OH})_{2}
$$

This results in the renewal of manganese dioxide on the surface of the material and the restoration of its initial state. In the described mechanism, manganese dioxide acts as an adsorbent and redox catalyst. According to the described mechanism, removal of iron from water occurs by oxidizing Fe (II) to Fe (III).

Conventional methods of underground water conditioning, i.e., aeration and filtration through sand beds, appear to be ineffective in the case of high concentration of iron and manganese, accompanied by high levels of ammonia nitrogen and hydrogen sulfide [26].

Studies [29] have shown that groundwater with an excessive iron $\left(>6.0 \mathrm{~g} / \mathrm{m}^{3}\right)$, manganese, and ammonium nitrogen content should be treated with two-stage filtration. Quartz sand should be used in the first stage as it effectively stops the iron compounds present in the water. However, in order to remove manganese and ammonium nitrogen, chemically active masses should be used-Greensand obtains the best results. Compared to Greensand, clinoptilolite beds are characterized by comparable efficiency in removing iron compounds but obtain worse results in reducing the content of manganese and ammonium nitrogen. The Crystal-Right 100 zeolite mass met the high requirements for the removal of iron, manganese, and ammonium nitrogen; however, impurities were removed in the adsorption and ion exchange processes, resulting in frequent regenerations of the bed and shorter working cycles compared to chalcedonite [29].

On the other hand, the removal of ammonium ions is possible only in the nitrification process involving the biofilm produced on the surface of the mineral. The high concentration of nitrite nitrogen in the water after the biofiltration process is a negative phenomenon due to the inhibition of the development of nitrifying bacteria on the biofilter filling [19]. In order to maintain the high activity of nitrifying microorganisms, commencing the second phase of nitrification as soon as possible and eliminating excessive accumulation of nitrite ions are both extremely important [33]. In the analyzed cases, the commencement of the second stage of nitrification occurred on days 51 (water I), 24 (water II), and 21 (water III) of the filter's operation, but higher increases in nitrate nitrogen were observed in the system without chemical activation (water III).

The lack of bed activation also contributed to an increase in the consumption of oxygen dissolved in the biofiltration process. Nitrification is a completely aerobic process, and so oxygen consumption indicates that biological processes are taking place on the filters. The total stoichiometric oxygen consumption in the nitrification reactions is $4.57 \mathrm{~g} \mathrm{O}_{2}$ per $1 \mathrm{~g}$ of ammonium nitrogen, whereas, in the case of iron and manganese oxidation, they are $0.14 \mathrm{~g} \mathrm{O}_{2} / \mathrm{g}$ Fe and $0.29 \mathrm{~g} \mathrm{O}_{2} / \mathrm{g} \mathrm{Mn}$, respectively [46]. In single-stage filtration with a water table above the filtration layer, in conditions of full saturation of water with oxygen $\left(10-16^{\circ} \mathrm{C}\right)$, it is possible to oxidize no more than approximately $2 \mathrm{~g}$ of N-NH${ }_{4}{ }^{+} / \mathrm{m}^{3}$. This limitation applies to biofiltration processes carried out in filters with a filling which does not take part in the process of removing impurities or which take part in this process to a small extent. The oxygen content below which the nitrification rate depends on the dissolved oxygen concentration is, respectively, $2 \mathrm{~g} \mathrm{O}_{2} / \mathrm{m}^{3}$ (for the first phase of the process) and $4 \mathrm{~g} \mathrm{O}_{2} / \mathrm{m}^{3}$ (for the second phase of the process). Too little a concentration of dissolved oxygen may cause the stopping of the biological oxidation reaction after the first phase of nitrification, which will result in an undesired presence of nitrite nitrogen in the water. Accumulation of nitrite ions is a negative phenomenon due to the inhibition of the growth of nitrifying bacteria. Nitric (III) acid produced from $\mathrm{NO}_{2}{ }^{-}$ions can be toxic to both Nitrosomonas and Nitrobacter. The observed oxygen consumption was significantly different from the theoretical oxygen demand and amounted to approximately 2-2.4 $\mathrm{g} \mathrm{O}_{2}$ for each $\mathrm{g}$ of nitrogen removed in the system with chemical activation, and approximately $3.2 \mathrm{~g} \mathrm{O}_{2}$ for each $\mathrm{g}$ of nitrogen removed in the system without activation (Table 7). 
Table 7. Comparison of parameters in the biofiltration process on chalcedonite beds.

\begin{tabular}{|c|c|c|c|}
\hline \multirow{2}{*}{ Parameters } & Water I & Water II & \multirow{2}{*}{$\begin{array}{c}\text { Water III } \\
\begin{array}{c}\text { Bed without } \\
\text { Pre-activation }\end{array}\end{array}$} \\
\hline & \multicolumn{2}{|c|}{ Beds Pre-activated } & \\
\hline $\begin{array}{l}\text { The amount of nitrogen removed } \\
\Delta{\mathrm{N}-\mathrm{NH}_{4}}^{+}\left[\mathrm{g} \mathrm{N}-\mathrm{NH}_{4}{ }^{+} / \mathrm{m}^{3}\right]\end{array}$ & $0-3.70$ & $0.1-3.5$ & $1.34-3.00$ \\
\hline $\begin{array}{l}\text { Amount of nitrite nitrogen formed } \\
\qquad \mathrm{N}-\mathrm{NO}_{2}{ }^{-}\left[\mathrm{g} \mathrm{N}-\mathrm{NO}_{2}-/ \mathrm{m}^{3}\right]\end{array}$ & $(-1.39)-2.04$ & $(-0.923)-2$ & $(-0.01)-2.09$ \\
\hline $\begin{array}{l}\text { Amount of nitrate nitrogen formed } \\
\Delta \mathrm{N}-\mathrm{NO}_{3}{ }^{-}\left[\mathrm{g} \mathrm{N}-\mathrm{NO}_{3}-/ \mathrm{m}^{3}\right]\end{array}$ & $(-1.20)-1.38$ & $(-2.5)-2.73$ & $(-0.02)-2.73$ \\
\hline Oxygen consumption $\Delta \mathrm{O}_{2}\left[\mathrm{~g} \mathrm{O}_{2} / \mathrm{m}^{3}\right]$ & $0-4.06$ & 0.52 & $4.12-8.43$ \\
\hline Efficiency of ${\mathrm{N}-\mathrm{NH}_{4}}^{+}$removal [\%] & $0-100$ & $2.85-100$ & $78-96$ \\
\hline Efficiency of Fe removal [\%] & $85-100$ & $93-100$ & $93-100$ \\
\hline Efficiency of Mn removal [\%] & $\begin{array}{l}(-34)-97 \% \\
\text { from } 57 \text { days, } \\
\text { washing out Mn to } \\
\text { the filtrate }\end{array}$ & $52-99 \%$ & $\begin{array}{l}\text { from } 28 \text { days } 0, \\
\text { washing out Mn to the } \\
\text { filtrate }\end{array}$ \\
\hline $\begin{array}{l}\text { Time to obtain a normative value } \\
\left(0.39 \mathrm{~g} \mathrm{~N}^{-N_{4}}{ }_{4}^{+} / \mathrm{m}^{3}\right) \text { [day] }\end{array}$ & 23 & 23 & 14 \\
\hline Oxygen consumption per $1 \mathrm{~g}$ of nitrogen $\left[\mathrm{g} \mathrm{O}_{2} / 1 \mathrm{~g} \mathrm{~N}\right]$ & 2.02 & 2.43 & 3.20 \\
\hline The start time of the I phase of nitrification [day] & 31 & 1 & 7 \\
\hline The start time of the II phase of nitrification [day] & 51 & 24 & 21 \\
\hline
\end{tabular}

For comparison, in the biofiltration process in a sand bed with gravitational flow, the consumption of oxygen for each $1 \mathrm{~g}$ of removed ammonium nitrogen was between $50-150 \%$ of the theoretical oxygen demand [47]. Such high oxygen consumption was explained by the biodegradation of dead organic matter accumulated in the bed. In the discussed case, in the first stage of biofiltration, anti-gravitational flow was used which favored a natural regulation of biofilm thickness and resulted in the successive removal of dead organic matter from the biofilter, and consequently, reduced oxygen consumption.

From the comparison of the biofiltration process in the analyzed filtration systems, it can be concluded that chemical activation has no effect on the efficiency of removal of iron and ammonium nitrogen but delays the start of both the first and second phase of the nitrification process. Activation of the bed positively influences the removal of manganese and results in less oxygen consumption in the treated water as compared with the bed not subjected to chemical activation (Table 7).

In the research conducted thus far, it has been demonstrated that the removal of manganese and iron from water is the result not only of physicochemical processes but also of the involvement of iron and manganese oxidative bacteria $[1,48]$. Other sources indicate that microorganisms may play a significant role in the formation process of the catalytic layer of manganese oxides; however, once the formation of this layer is completed, manganese oxidizing bacteria do not affect the efficiency of manganese removal from water [28]. The mechanism of the removal of manganese process with the simultaneous removal of ammonium nitrogen has been previously described in the literature $[3,19,27,29,49]$. Slight changes in nitrate concentration and reduced manganese removal efficiency may explain the delay of the nitrification process due to the reaction of nitrites with manganese dioxide. The deposits are not subjected to a desorption process, but only to a periodic rinsing to remove accumulated sediments. The sorption properties of chalcedonite and the ability to retain the water microorganisms that cause the biofilm formed on its surface takes over the sorbent functions and uses the retained substances for the development and multiplication of bacterial cells. The creation of biofilms and the formation of manganese oxide coatings on the surface of chalcedonite causes the deposit to work continuously (does not run out). For that very reason, the Thomas model commonly applied to describe the continuous column system [30] may not be used. 


\section{Conclusions}

1. The removal of ammonium nitrogen, iron, and manganese in the biofiltration process on chalcedonite beds is an alternative method to conventional processes used in water treatment plants-filtration on quartz beds. Chalcedonite has greater porosity and a more proper surface than quartz sand. It is a better substrate for immobilization and development of microorganisms involved in the biodegradation of pollutants, which allows for simultaneous removal of $\mathrm{NH}_{4}{ }^{+}$, $\mathrm{Mn}$, and Fe according to different types of mechanisms.

2. Among the analyzed systems, the best efficiency of removing ammonium nitrogen, iron, and manganese from groundwater was demonstrated by two-stage biofiltration on chalcedonite beds, with initial chemical activation at the first stage of filtration.

3. Chemical activation of the chalcedonite bed had an effect on the efficiency of removal of manganese (II) ions but did not affect the efficiency of iron removal.

4. In the pre-activated bed system, a longer biofilm formation time (start-up of the bed) was observed, which resulted in a longer waiting period for obtaining the required concentration of ammonium nitrogen in the treated water.

5. Activation of the bed with potassium manganese (VII) reduces the oxygen consumption in the biofiltration process as compared with the non-activated bed. The oxygen deficiency can inhibit the ammonium nitrogen removal process.

6. The sorption properties of chalcedonite and the ability to retain water borne microorganisms that cause the biofilm formed on its surface takes over the sorbent functions and retained ammonium ions processing the construction of new bacterial cells. The creation of biofilms and the creation of manganese oxide coatings results in continuous filter operation. Filling the biofilter does not require regeneration.

Author Contributions: Conceptualization, D.P., A.P., J.K. and A.D; methodology, D.P., A.P. and J.K.; validation, D.P., A.P. and J.K.; formal analysis, D.P. and A.D.; writing-original draft preparation, D.P., A.P. and J.K.; writing-review and editing, A.D. and D.P.; visualization, A.D.; supervision, D.P.; project administration, D.P.; funding acquisition, D.P., A.P., A.D and J.K.

Funding: This research was funded by subsidies for statutory activity (number: DS.BO.17.001).

Conflicts of Interest: The authors declare no conflict of interest.

\section{References}

1. Sharma, S.K.; Petrusevski, B.; Schippers, J.C. Biological iron removal from groundwater: a review. J. Water Supply Res. Technol. AQUA 2005, 54, 239-247. [CrossRef]

2. Haddad, M.; Ohkame, T.; Bérubé, P.R.; Barbeau, B. Performance of thin-film composite hollow fiber nanofiltration for the removal of dissolved Mn, Fe and NOM from domestic groundwater supplies. Water Res. 2018, 145, 408-417. [CrossRef] [PubMed]

3. Yang, H.; Li, D.; Zeng, H.; Zhang, J. Autotrophic nitrogen conversion process and microbial population distribution in biofilter that simultaneously removes $\mathrm{Fe}, \mathrm{Mn}$ and ammonia from groundwater. Int. Biodeterior. Biodegrad. 2018, 135, 53-61. [CrossRef]

4. Abu, H.H.; Sheikh, A.S.R.; Kamarudin, S.K.; Tan, K.N. On-off control of aeration time in the simultaneous removal of ammonia and manganese using a biological aerated filter system. Process Saf. Environ. Prot. 2013, 91, 415-422. [CrossRef]

5. Cheng, Q.; Nengzi, L.; Bao, L.; Huang, Y.; Liu, S.; Cheng, X.; Li, B.; Zhang, J. Distribution and genetic diversity of microbial populations in the pilot-scale biofilter for simultaneous removal of ammonia, iron and manganese from real groundwater. Chemosphere 2017, 182, 450-457. [CrossRef] [PubMed]

6. Tekerlekopoulou, A.G.; Vayenas, D.V. Ammonia, iron and manganese removal from potable water using trickling filters. Desalination 2007, 210, 225-235. [CrossRef] 
7. Huang, B.; Li, Z.; Chen, Z.; Chen, G.; Zhang, C.; Huang, J.; Nie, X.; Xiong, W.; Zeng, G. Study and health risk assessment of the occurrence of iron and manganese in groundwater at the terminal of the Xiangjiang River. Environ. Sci. Pollut. Res. 2015, 22, 19912-19921. [CrossRef]

8. Zoni, S.; Albini, E.; Lucchini, R. Neuropsychological testing for the assessment of manganese neurotoxicity: A review and a proposal. Am. J. Ind. Med. 2007, 50, 812-830. [CrossRef]

9. Tekerlekopoulou, A.G.; Pavlou, S.; Vayenas, D.V. Removal of ammonium, iron and manganese from potable water in biofiltration units: a review: Removal of ammonium, iron and manganese from potable water. J. Chem. Technol. Biotechnol. 2013, 88, 751-773. [CrossRef]

10. Li, D.; Liu, S. Groundwater Quality Detection. In Water Quality Monitoring and Management; Elsevier: Academic Press: London, UK; San Diego, CA, USA; Cambridge, UK; Oxford, UK, 2018; Volume 1, pp. $269-302$. [CrossRef]

11. Commission Directive (EU) 2015/1787 of 6 October 2015 amending Annexes II and III to Council Directive 98/83/EC on the Quality of Water Intended for Human Consumption. Available online: https://eurlex.europa.eu/legal-content/EN/TXT/?uri=uriserv\%3AOJ.L_.2015.260.01.0006.01.ENG (accessed on 14 February 2019).

12. Puszkarewicz, A.; Kaleta, J. Highly effective conditioning of underground waters with the use of catalytic preparations. Ecol. Technol. 2006, 14, 23-29.

13. Kaleta, J.; Kida, M.; Koszelnik, P.; Papciak, D.; Puszkarewicz, A.; Tchórzewska-Cieślak, B. The use of activated carbons for removing organic matter from groundwater. Arch. Environ. Prot. 2017, 43, 32-41. [CrossRef]

14. Jordanowska, J.; Jakubus, M. Evaluation of effectiveness technological process of water purification exemplified on modernized water treatment plant at Otoczna. Civ. Environ. Eng. Rep. 2014, 13, 49-62. [CrossRef]

15. Štembal, T.; Markić, M.; Ribičić, N.; Briški, F.; Sipos, L. Removal of ammonia, iron and manganese from groundwaters of northern Croatia-pilot plant studies. Process Biochem. 2005, 40, 327-335. [CrossRef]

16. Vries, D.; Bertelkamp, C.; Schoonenberg Kegel, F.; Hofs, B.; Dusseldorp, J.; Bruins, J.H.; de Vet, W.; van den Akker, B. Iron and manganese removal: Recent advances in modelling treatment efficiency by rapid sand filtration. Water Res. 2017, 109, 35-45. [CrossRef]

17. Nitzsche, K.S.; Weigold, P.; Lösekann-Behrens, T.; Kappler, A.; Behrens, S. Microbial community composition of a household sand filter used for arsenic, iron, and manganese removal from groundwater in Vietnam. Chemosphere 2015, 138, 47-59. [CrossRef]

18. de Vet, W.W.; Dinkla, I.J.; Rietveld, L.C.; van Loosdrecht, M.C. Biological iron oxidation by Gallionella spp. in drinking water production under fully aerated conditions. Water Res. 2011, 45, 5389-5398. [CrossRef]

19. Papciak, D.; Zamorska, J. Single and two-layer nitrifying beds for bio-technologic method of removing ammonium nitrogen from water. Biotechnology 2008, 1, 189-201.

20. Papciak, D.; Zamorska, J. The biofilters fillers with reference to effectivity of nitrification process. In Scientific Papers of Rzeszow University of Technology; Publishing House of the Rzeszow University of Technology: Rzeszów, Poland, 2003; Volume 35, pp. 147-160. (In Polish)

21. Papciak, D. Effect of Nitrification-Filter Packing Material on the Time to Reach its Operation Capacity. In Environmental Engineering; Pawłowski, L., Dudzińska, M., Pawłowski, A., Eds.; Taylor \& Francis Group: London, UK, 2007; pp. 125-132.

22. Ruiz, M.; Roset, L.; Demey, H.; Castro, S.; Sastre, A.M.; Pérez, J.J. Equilibrium and dynamic studies for adsorption of boron on calcium alginate gel beads using principal component analysis (PCA) and partial least squares (PLS). Materialwiss. Werkstofftech. 2013, 44, 410-415. [CrossRef]

23. Jeż-Walkowiak, J.; Dymaczewski, Z.; Szuster-Janiaczyk, A.; Nowicka, A.; Szybowicz, M. Efficiency of Mn removal of different filtration materials for groundwater treatment linking chemical and physical properties. Water 2017, 9, 498. [CrossRef]

24. Albrektiene, R.; Rimeika, M.; Voisniene, V. The Characterisation of Natural Organic Matter in Ground Water Using Rapid Fractionation. In Proceedings of the Water Pollution 2014, The Algarve, Portugal, 26-28 May 2014; pp. 111-120. [CrossRef]

25. Albrektienè, R.; Rimeika, M. Efficiency of Removal of Iron, Manganese, Ammonium and Organic Matter from Groundwater. In Proceedings of the Environmental Engineering, Vilnius, Lithuania, 27-28 April 2017. [CrossRef] 
26. Kaleta, J.; Puszkarewicz, A.; Papciak, D. Removal of iron, manganese and nitrogen compounds from underground waters with diverse physical and chemical characteristics. Environ. Prot. Eng. 2007, 33, 5-13.

27. Papciak, D.; Zamorska, J.; Kaleta, J.; Puszkarewicz, A. Effect of manganese (II) on the time of biofilm formation and on the effectiveness of ammonium nitrogen removal from water in biofiltration process. Pol. J. Environ. Stud. 2009, 2, 43-45.

28. Sozański, M.M.; Jeż-Walkowiak, J.; Weber, Ł. Methods of research on technological suitability of filtration materials for iron and manganese removal from groundwater based on tests with chalcedonit bed. Instal 2011, 10, 61-65.

29. Kaleta, J.; Puszkarewicz, A.; Papciak, D. Natural and modified minerals in remediation of groundwaters. Economy Min. Resour. 2009, 25, 51-63.

30. Demey, H.; Lapo, B.; Ruiz, M.; Fortuny, A.; Marchand, M.; Sastre, A.M. Neodymium recovery by chitosan/iron(III)hydroxide [ChiFer(III)] sorbent material: Batch and column systems. Polymers 2018, 10, 204. [CrossRef]

31. Katsoyiannis, I.A.; Zikoudi, A.; Hug, S.J. Arsenic removal from groundwaters containing iron, ammonium, manganese and phosphate: a case study from a treatment unit in northern Greece. Desalination 2008, 224, 330-339. [CrossRef]

32. Michel, M.M. Characteristics of chalcedonite from Teofilów deposit for possible use in technology of water and wastewater treatment. Economy Min. Resour. 2011, 27, 49-67.

33. Michel, M.M.; Kiedryńska, L.; Tyszko, E. Manganese removal from groundwater on modified chalcedonite and Purolite MZ-10 beds. Environ. Prot. 2008, 30, 15-20.

34. Kasza, B.; Naziemiec, Z.; Pabis, J. Utilization chalcedownite waste from the Inowłódz mine. In Proceedings of the Conference Materials on Economy of Mineral Raw Materials from Mining and Energy, Przegorzały, Poland, 1996; Volume 1, pp. 1-6. [CrossRef]

35. Tchórzewska, D.; Pabis, J.; Kosk, I.; Nieć, M. New applications of chalcedonite as a sorbent in the water treatment process. Geol. Rev. 2001, 49, 303-306.

36. Clack $\mathrm{MTM}^{\circledR}$ is Used for Reducing Iron, Manganese and Hydrogen Sulfide from Water Supplies. Available online: http://www.clackcorp.com/downloads/ion_exchange_resin_and_filter_media/mtm_2353.pdf (accessed on 14 February 2019).

37. Clack MTM ${ }^{\circledR}$ Safety Data Sheet. Available online: http://www.clackcorp.com/downloads/msds/Active $\%$ 20Online\%20Filter\%20Medias/MTM-EU.pdf (accessed on 14 February 2019).

38. Greensand Plus-Technical Data. Available online: https://www.inversand.com/wp-content/uploads/ 2018/02/Greensand-Technical-Data.pdf (accessed on 14 February 2019).

39. Greensand Plus ${ }^{\mathrm{TM}}$ _Safety Data Sheet. Available online: http://www.clackcorp.com/downloads/msds / Active\%20Online\%20Filter\%20Medias / A8042\%20GreensandPlus\%20SDS\%208-20-2015.pdf (accessed on 14 February 2019).

40. Catalyst G1. Available online: http://gc2000.pl/wp-content/uploads/docs/G1.pdf (accessed on 14 February 2019).

41. Defeman Deposit. Available online: http://gc2000.pl/wp-content/uploads/docs/DEFEMAN.pdf (accessed on 14 February 2019).

42. Multiman 3M-Filtration Media. Available online: http://www.dynamikfiltr.pl/df_files/files/pl_74_pl_9_ ZLOZE_FILTRACYJNE_MULTIMAN_3M.pdf (accessed on 14 February 2019).

43. Pyrolox ${ }^{\circledR}$ _Filtration Media. Available online: http://www.clackcorp.com/downloads/ion_exchange_ resin_and_filter_media/pyrolox_2356.pdf (accessed on 14 February 2019).

44. 2018 Pure Water Commercial Catalog. Available online: https://www.watts.com/dfsmedia/ 0533dbba17714b1ab581ab07a4cbb521/29526-source/options/download/c-wq-purewatercommercial (accessed on 14 February 2019).

45. Filtration Media. Available online: https://www.swtwater.com/catalog/pdf/1093\%20-\%20MetalEase.pdf (accessed on 14 February 2019).

46. Cai, Y.; Li, D.; Liang, Y.; Zeng, H.; Zhang, J. Operational parameters required for the start-up process of a biofilter to remove $\mathrm{Fe}, \mathrm{Mn}$, and $\mathrm{NH}_{3}-\mathrm{N}$ from low-temperature groundwater. Desalin. Water Treat. 2016, 57, 3588-3596. [CrossRef]

47. Pruss, A. Contribution of biofilm thickness on sand filter grains to oxygen uptake during ammonia nitrogen removal. Environ. Prot. 2007, 29, 5-39. 
48. Das, A.P.; Sukla, L.B.; Pradhan, N.; Nayak, S. Manganese biomining: A review. Bioresour. Technol. 2011, 102, 381-7387. [CrossRef]

49. Papciak, D.; Kaleta, J.; Puszkarewicz, A. Removal of ammonia nitrogen from groundwater on chalcedony deposits in two-stage biofiltration process. Annu. Set Environ. Prot. 2013, 15, 1352-1366. 